RESEARCH ARTICLE

\title{
The Role of Iberian Institutions in the Evolution of Macao
}

\author{
Mingchen Sun \\ Hengsheng Science and Technology Development Co., Ltd, Macao, China
}

\begin{abstract}
Since around 1555, the Portuguese had as of now gotten comfortable Macao. Albeit encompassed by Chinese urban areas, Macao oversaw for quite some time to save and foster the Portuguese attributes that are clear in the city design. This western trademark is the thing that these days makes Macao not the same as its neighbors and is the foundation of the city's special "Social Identity" (CI). The city CI is such a significant element that the People's Republic of China proposed to UNESCO that they remember Macao for the World Heritage list. Taking into account that over $95 \%$ of the populace is of Chinese beginning, we currently bring up a significant issue: what was the course of Macao's establishment and how could it be to keep up with the Portuguese qualities for such a long time in the midst of an ocean of Asian development and culture? The response is significant, in understanding the city's set of experiences, yet additionally to make it conceivable to safeguard the Macao CI for people in the future. Following a near strategy for examination of the similitudes and contrasts with other abroad Portuguese urban areas in Asia, and in the wake of investigating the chronicled development of Macao, we recognized the critical components and hints that could give the response to this significant inquiry. The finishes of the examination highlight the recognizable proof of the Portuguese standards for settling, and the Iberian foundations' liability in keeping up with the Portuguese qualities that mirror the city's social association. The western social personality of the city was produced by its Iberian foundations through a viable equal improvement with the Chinese towns which involve a similar landmass.
\end{abstract}

Keywords: Macao development; Portuguese overseas cities; Cultural identity; Iberian institutions; Military; Religious and civic buildings

Citation: Mingchen Sun, 2018. The Role of Iberian Institutions in the Evolution of Macao. Journal of Sustainable Urbanization, Planning and Progress, 3(1): 32-38. http://doi.org/10.26789/JSUPP.2018.01.005

Copyright: The Role of Iberian Institutions in the Evolution of Macao. (C) 2018 Mingchen Sun. This is an Open Access article published by Urban Development Scientific Publishing Company. It is distributed under the terms of the Creative Commons Attribution-Noncommercial 4.0 International License, permitting all non-commercial use, distribution, and reproduction in any medium, provided the original work is properly cited and acknowledged.

\section{Introduction}

Macao was brought into the world in similar period as the many other new Iberian urban areas, towns and settlements of the Iberian Empire in America, Asia and Africa. The manner in which Macao was established and assembled mirrored the social Portuguese underlying foundations of middle age urbanism and design. These urban areas like Colombo, Macao, Manila, Malacca, Goa, and so on, shaped an exceptionally enormous organization of all around found metropolitan constructions, which spread out and adjusted to various areas, environment, and geographical characteristics. To appropriately restore these old Iberian urban areas, it is vital to comprehend the justifications for why these urban communities where established in specific places, and decide the standards for their association and the organizations behind their turn of events. The Chinese city in Macao created in corresponding with the Western or Christian city whose fun- damental pivot was the Rua Direita. The Western city favors receptiveness to the International region and appearances the Outer Harbor. The Chinese city searches internally as to Mainland China and countenances the Inner Harbor. Macao, as the city of two harbors, is frequently portrayed by painters. The appeal of Macao additionally comes from the way that it was the principal western city in Asia. Macao's uniqueness is the fundamental explanation for the proposition for UNESCO to characterize the city as a World Heritage Site. To keep up with this uniqueness is significant in regarding the city's practices and Cultural Identity, a legacy of 400 years of Iberian and Chinese interaction. For this purpose a comprehensive urban rehabilitation Programme was implemented in the Historical Center of Macao.

\section{Method}

After a comparative survey of the common character- 
istics of Macao with other Iberian overseas cities in the region, we are able to establish patterns ranging from their geographic conditions to their urban organization. The second step is to find the reasons behind these common patterns. The third step is to determine the reasons why the Western city of Macao survives in a different culture and within a compatible or complementary Asian environment.

Historical data and the above mentioned elements are necessary requirements in establishing the basic factors concerning the fabric of its urban organization and city development. A description of the historical process is important to an understanding of the city's evolution and in determining the role of its Iberian institutions. Historical description not only facilitates an understanding of Iberian urban practices, but also is a necessary "inspirational" factor for the new projects of urban rehabilitation that are focused on the preservation of the city's Cultural Identity.

\section{Common Patterns}

Overseas Iberian cities share several characteristics of Lisbon, the Portuguese capital. After analyzing the data, the predominance of peninsulas as the preferred place for settling becomes apparent. The foundation of Macao follows the same urban patterns as the traditional Portuguese seashore cities, which definitely share many characteristics with Lisbon, the Portuguese capital in the Iberian Peninsula. These common patterns where not established predefined colonial rules, determined by the monarchs in Lisbon, but principles which were assumed by the Iberian captains of the fleets.

\section{Comparative Patterns in Iberian Settlements}

With the cities' development, situations changed because of the tendency of extending the city to flat areas to facilitate the construction of buildings and the road systems. The regular grid was progressively preferred over the organic development for predominantly irregular terrains. The parameters mentioned below contribute in defining the Portuguese preferences for choosing a settlement site and its immediate development.

\section{Portuguese Principles}

Data help to extrude a few principles practiced by Portuguese for choosing the settling place. These principles can be summarized as follows:

A) Strategic geographic position on islands or peninsulas for supporting the sea trade and defense by having an open communication with other allied cities of the Seaborne Portuguese Empire. This network of cities stretched its trade, political and cultural influence from Colonia de Sacramento in Uruguay to places as far away as Macao and Nagasaki;

B) Availability of shelter bays with easily accessible water and food supplies was essential for ship maintenance, repair, refueling and protection during the winter and monsoon periods;

C) Occupation of the places with hills. High ground always proved to be a safe place for defense purposes and an inspiring location for religious buildings. If attacked (very frequent in the past) they could easily defend themselves with a small garrison. Bocarro (1642) makes all the above-mentioned considerations evident in his book for the eyes of the king, like the representation of Malacca.

\section{Overseas Differences among Iberian Nations}

Although Portuguese and Spaniards have a common cultural background, and shared the same rulers for some periods, they have clear cultural differences, which are apparent for example, in choosing the place for founding a city. Most of the old American towns of the United States, Mexico, Argentina, Brazil, Peru, the Philippines, etc., are urban heritages of the Iberian period. We can call them Macao's sister cities. In general, we can observe that the Spaniards founded new cities like Manila and Vigan by following the Renaissance theories. They favored the square grid, an influence of the ancient rules laid down by Hippodamus from Mileto in the 5th century B.C. (the first known urban planner) and the Roman military founded colonies. It is common knowledge that in the foundation of their cities, the Spaniards applied many rules and few principles. The Portuguese followed a different style of applying few rules but more principles as mentioned above, which favors an organic development.

\section{Chinese Principles}

The most significant Chinese principles are observed in the Chinese communities of Macao when they chose their place for settling. According to Chinese tradition, building a house or a city must follow the Fung Shui (meaning "wind and water") rules in order to attract good luck and prosperity. To act in accordance with or in opposition to the Fung Shui principles is believed to bring about good or disaster, respectively. For the geographic analysis, we will just consider a few principles, which are more relevant in the formation of the Chinese settlements in Macao:

1) A flat place with a hill at the back, preference of protection from the north winds, avoiding high places because good luck will roll run down the hill. 
2) Location near bodies of water which represent prosperity and life.

3) Avoid sharp objects, streams, locations that bring "Chi" (Taoist concept of energy that could have negative effects) to the house. A screen and a mirror is said to protect the house from the negative "Chi".

4) Entrance orientated towards the South, which brings light and good luck.

5) Other principles related to Ying and Yang are practiced in houses as well as in gardens. Ying and Yang correspond to two complementary principles in Chinese metaphysics. Ying is negative, dark and feminine, while Yang is positive, bright, and male, and both are part of the design process towards attaining the harmonizing of such principles in an open or enclosed space.

The first and second 'Fung shui' principles mentioned above are popularly known, as 'bui san min hoi' and are auspicious requirements, which literally mean 'mountain in the back and water in front'.

Because in China bureaucrats rule the city, a grid based geometric organization facilitates the keeping of the social order and the daily administration. This pragmatic approach influenced the cities' urban design. The separation of districts or city blocks and walled wards for different functional areas was common practice in Chinese cities and particularly characteristic of the Tang dynasty (618 - 907). In Macao, visiting Mandarins often stayed in important temples like the Ling Fong (Lotus). As in the case of Imperial China, the administrative and the commercial urban areas in Macao were separated, and functioned as semi-independent units inside the same city. At Changan and Luoyang, the bureaucrats were the link between the two most important social levels in the city, namely; the Aristocrats and the Merchants. The commercial activities assumed by the lower classes could not mingle with the upper social levels formed by the Aristocrats and Bureacrats.

\section{Compatibility of Principles}

The Portuguese preference for high ground was considered as inviting bad luck, inauspicious, and against Fung Shui Principles. The flat land in front of the river, the Inner Harbor, was busy with activity was an auspicious location for development. Temples and Chinese settlements sprawled in these areas with easy access to China. The Outer Harbor, which faces south was even better in terms of Fung Shui, but was exposed to typhoons, and pirate attacks. It was first occupied by the Portuguese who, being mainly busy with seasonal trading activities, left the manual work and farming to the locals. Chinese and Portuguese principles complemented each other and contrib- uted to the occupation of the available hill and flat lands. Complementary activities economically favored both communities, and this mutually beneficial formula was the principle for a stable relationship that lasted for centuries.

\section{Macao Development}

Situated at $113^{\circ} 31^{\prime} 36^{\prime \prime}$ and $22^{\circ} 06^{\prime} 39^{\prime \prime}$ latitude, Macao is $4,2 \mathrm{Km}$ in length and has a width varying from 320 meters in the narrow area between Praya Grande to Rua dos Mercadores, to 1.500 meters from the Patane area to the Guia Hill seashore. The island was progressively linked with Mainland China by a tiny sand strip and is punctuated by five bare and rocky low hills; the tallest is Guia (meaning to "guide" in Portuguese), which reaches 91 meters in height. There is a small probability (but no historical or archeological evidence) that at the time of the arrival of the Portuguese ships to Macao, they met Chinese from Fujian with provisional dwellings for their rest period between trips or for taking shelter during stormy periods. Macao was the improvised winter shelter and convenient market place while waiting for the right season to go and sell products in Canton. These economic activities soon attracted foreigners and Chinese to the area. New settlements developed with immigrants from Guangdong and Fujien provinces and the hard settling Hakkas (meaning guests). Each of these groups had different dialects and professional activities. These settlements were named as Patane, Barra, and Mong Ha, each one of which had a different urban development and were apparently isolated or had little communication with each other, probably because of their different clan origins, dialects and professions. Each one of these areas would have had a different urban development as a consequence of their relationship with the Western city of Macao. As it is a traditional practice in China, and is infl uenced by the propitious conditions of Fung Shui, Mongh Ha Village was located outside the walls of the Christian city, under the shadow of the nearby hill, while facing water in the south. A small shrine near the actual temple of Gun Ian Jai (small Gum Ian), which was built in the foothills in the 7th year of the Ming Emperor Tianchi (1627), was surrounded by rice fi elds and irrigated by the branch of a river. Years passed and a new temple was erected a few meters away that eventually became a Buddhist monastery during the Qing Dynasty. On the northern slope of the same hill, the Ling Fong temple served as the Chinese administrative and political center of the city. Apparently, the administrative function was established only after the commercial settlements and the fishermen's villages were already developed. This function was needed in order to manage all the Chinese citizens in the other settlements, and served as an offi cial 
representative place that was visible to the foreigners in Macao. Lin Fong temple was also the residential place for the visiting Mandarins from China. Presently, there are 43 temples in Macao. The majority of them contain a mixture of Buddhist, Taoist and folk religious deities. In the oldest western maps, only Mongh Ha village was represented. The Macao Peninsula was closed in its northern tip by a wall and a gate controlled by a Chinese garrison.

\section{Portuguese Settling in Macao}

The first residences for Westerners were the wooden ships anchored in the Inner Harbor. Timidly, they started encamping on the Inner Harbor beach and the Camoes garden. The encampment area was protected by a timber palisade fence, a common Portuguese practice inherited from the Roman period.

The Portuguese settlement started to consolidate after the peaceful negotiations between the Haidaofushi, or Aitao (Deputy Superintendent of Maritime Affairs) of Guangdong; Wan Bo and Captain Leonel de Sousa. Progressively more solid structures replaced the provisional timber and straw dwellings. First of all were the churches, followed by the warehouses, and then the residences, which, according to the 17th century Bocarro description, were mostly of two to three floors with gable-tiled roofs. Some churches and public buildings had more elaborate roofs. The first churches where near the actual church of St. Antonio. Portuguese seafarer merchants, religious and adventurers started the occupation of a small piece of triangular land in the empty peninsula of Macao, which was bounded by the Monte, Guia and Penha Hills. Different religious orders occupied separate parts of the empty land. Fortified positions occupied the hills and the ends of the Praya Grande beach. The city developed fast in a disorganized way. In 1565 , there were already more than one thousand houses built for foreign merchants, their families and servants.

In the 17th century, new residential areas where created in the Inner Harbor, and outside the city's western wall through land reclamation. The old predominant "image" of Macao was located in the exterior harbor, the "Praia Grande" (long beach) where a row of western houses, extended some 700 yards in a pleasant promenade covered with trees along the crescent shape of the bay. The Chinese city was located towards the Inner Harbor and the surrounding streets of the western urban nucleus. The Christian city was organized along the Rua Direita, which literally means the Right street towards (name of the place), which in this case is the cathedral. This is a very old street formula denomination used in the Portuguese Middle Ages. This street was the city's main axis which links with the perpendicular side alleys to the Senate and the street leading to St. Paul College, and continues up to the city gate behind St Anthony Church. The last decade of the 16th century and the first two decades of the 17th century correspond to a wealthy commercial period that made the city grow and develop extremely fast within the walls ("Intramuros"). These three decades witnessed the construction of all the military, religious, civil and commercial structures in stone or timber, as well as the urban organization around these religious complex nucleons while adapting to the topographic conditions of the terrain. Papers on the SPC (Saint Paul College) by Pinheiro, Yagi and Korenaga (2005) and Amaro (1996) demonstrated the role of the religious institutions in the organization of the city layout and first development. Further development occurred by urban density concentration (vertical growth) and extension throughout the land reclamation (horizontal growth) and up to the seashores of the Inner and Outer Harbors. Only in the 19th century did the "Christian" city break its walls and extend towards the border with China. This increased the available land for construction by resorting to land reclamations from the beaches to the river. This expansion policy through the construction of modern infrastructures permitted Macao to become the most densely populated city in the world in the 20th century.

\section{Iberian Institutions in Macao Development}

The first western settlers in Macao have Mediterranean origins, with a predominance of people coming from the Iberian Peninsula. After the fall of the Roman Empire and the invasions of the barbaric tribes, Spanish and Portuguese societies underwent a deep structural change. The Visigoth period and Arab era (approximately 5 centuries in Portugal and 7 centuries in Spain) contributed to the shaping of the Iberian medieval society as well the cities. The Iberian society of the overseas expansion period was a Christian medieval society strongly influenced by Mudejar and renaissance culture under the rule of a centralized-but not absolute-monarchy, and supported by the national and regional parliaments (courts). This Iberian society was stratified in three different social layers:

Social Institutions like the military, merchants and the religious had a great influence in the organization of the Western city. The Catholic Church had primordial rule during the foundational years. Macao was upgraded in 1583 from a village to a city due to the large population dwelling in the town. This is one of the fastest growths and escapes from the natural rural genesis of any Portuguese city. Macao is, in the first place, a city created by merchants and religious people, which was later on protected by military constructions. The religious institutions 
mentioned in this paper are the ones separated from the traditional diocesan structures that are common in most Christian and even non- Catholic societies. Spanish monarchs from 1580 to 1640 ruled the two Iberian countries. They fostered under their direct patronage (the Spanish "Patronato Real and the Portuguese "Padroado") the spread of Catholic religious orders. With royal patronage, the overseas missions of the Jesuits; Franciscans; Augustinians and the Dominicans were particularly successful.

\section{The Religious Complex}

Macao's old name, which was used for centuries, was: "The City of the Name of God in China". In America and Asia, the religious communities established their respective apostolic and social works (more than 300 of them are founded all over the Philippines) by building churches, schools, orphanages, homes for the aged, courtyards, farms, and hospitals. This pioneering activity in Macao was followed by the organization of the first Western hospital, the first library, with more than 5,000 books of Asian and Western origins, the first Western printing press, etc. It is not surprising that the Jesuits also built Monte Fort and walled the entire Saint Paul College perimeter in order to safeguard these facilities' while transforming Monte hill into the Macao Citadel. Religious orders in Macao, like the Augustinians, Franciscans, Jesuits and Dominicans among others, clustered their buildings (church, convent, workshops, etc), forming urban complexes independent from the city. In fact the first Christian monasteries or convents where built in order to provide physical separation from the cities, facilitating in this way religious contemplation. Convents catalyzed the urban growth. Commoners built their houses under the support and protection of these religious complexes, which were well protected by walls and by their strategic positions as mentioned in previous papers on the Macao city development. A military network established the protected limits of the city. Often, Military facilities share with or are neighbors of religious compounds. This was the organic formula for the growth of this western city. The "Plaza" central building is usually a church such as the church of St. Lawrence, St. Augustine, St. Dominic, St. Anthony, St. Lazarus, the Cathedral, and St. Paul College. This grouping of religious buildings forming a "complex" became the central gravitational spot from where the city grew. Different religious orders have different preferences when choosing the proper place for their convents. According to Rosa, Walter (1997), the Jesuit convents were intended to be in the center of the city, while the Franciscans prefer the outskirts and peaceful places of the city. Their function as urban catalysts definitely ended in the first quarter of the 19th century.
Starting in 1789, religious buildings like St. Paul College were used as barracks for troops. In the 1830's, all other monasteries in Macao followed the same fate, either by adaptation (St. Paul, St. Dominic and St Augustine) or by total demolition (St. Francisco and Penha Convents). St. Dominic Monastery, located at the city center, survived only after being adapted to serve as a fire station.

\section{The Fortifications Network}

The first Western fortified position in Macao was in the inner Harbor, near the Camoes Garden. Antonio Bocarro mentions in his book on the Fortresses of Oriental India that "this city has a Captain General, which manages the military issues with 150 soldiers. After arrival, the defense was based in the artillery pieces and individual fire weapons mounted in the ships that formed the first defensive line. Larger ships like the Galleons or carracks were like sea-castles but slow moving. Patachos (light frigate) and gales were the most use in offensive operations." 1990's archeological excavations revealed the stone foundation of a three-floor artillery tower on the top of Monte Hill. In 1617, Monte Fort, which was used mainly as a protected recreation site for the Jesuits from St Paul College, was adapted in 1623 to work as a modern fortress and as the centerpiece and command of the Macao defense network. The military buildings contributed to the city layout and the organization of the urban planning inside the walls. The Captain General was the military governor of the forts and their garrisons. The military was an important institution in the shaping of the city and in keeping it for centuries inside the defensive walls. Walls were accessed by gates. In Macao, there were four main gates facing the northern part of the city namely, the St. Paul Gate called the Great Gate in Chinese (Damen yi or Sanba men); the small St. Paul Gate (Xiao Sanba Men); the Patane Gate (Shali Tou Men); and the Temple Gate (Huawangmiao Men). In the 19th century, the Campo Gate and another one called the New Gate (XinKai or Seng Hoi) were opened.

After the protection from the ships, the second defensive line was the provisional timber fences on the beaches located a short distance from the ships. The Spaniards, the Portuguese and the Dutch would search for safe harbors that could provide a stable position for warehouses for their goods, as "factoria" (trading center and storehouses), and where it was possible to build a small settlement. The ideal position was with two harbors: one, which was open to the sea and the second one with a difficult entrance for warships, which would need to be pulled by smaller boats. The perfection of making canons brought to an end the medieval defensive system, since high stone walls could easily be destroyed. The new defensive design acquired a lower profile, but larger in size and weight to better resist 
the impacts of the cannon balls. The fleet commander Tristao Vaz built the first walls in granite in 1568. These stone walls were soon substituted by the Taipa walls. Taipa is the name given to Earthwork construction resulting from the compact mixing of clay, pebbles, straw, and the lime obtained from burned crushed oyster shells (know as Chunambo). Granite was the solid stone foundation for these Taipa walls. Timber boards contained the Taipa mixture until it was dry.

\section{Survival and Cultural Identity}

In the era of globalization, new and old cities have to struggle to acquire or keep their soul or identity. Classifying or protecting a few isolated buildings is not sufficient guarantee for the preservation of a city's cultural identity. This identity is a collective identity - achieved by a cluster of buildings and spaces, which form a harmonious entity and give meaning (and feeling) to the place. A wellknown example is the Forbidden City in Beijing, where a compound of 9,999 buildings communicates to us down through the centuries the image of the mighty power, majestic grandeur and ancient culture of the Chinese Dynasties that form part of the common heritage of the Chinese people. Macao's classic image is obtained from a group or cluster of buildings linked by squares and narrow streets.

The "globalization" threat is present when developers intend to "modernize the city" anywhere and at any cost. This was the main cause of damage or destruction of the cultural heritage. However, this conflict of opposite alternatives between Heritage and (or versus) Development is an artificial one because it has been demonstrated by the successful guidelines and policies implemented in historical cities such as Rome, Venice, Xian, Seville, etc. Macao can only maintain its social heritage, culture and economic prosperity based on tourism if the historical urban characteristics are well preserved. Without this, Macao will be lost. It would be merely one more city that has been absorbed by its growing neighbors. Macao's effort to separate the development of residential, industrial and entertainment areas from the historical center is contributing to the preservation of the city's CI.

The religious, military and civil networks survived in the Historical Center of Macao. The focus of the Macao urban rehabilitation by the Municipal government is the Historical (Western) Center of Macao due to its classic ambience, and is mentioned in the UNESCO proposal for World Heritage as the Heritage corridor unifying 24 historical buildings and seven squares. In this preservation project, it is important to guarantee the conversion of the old streets from traffic to pedestrian use as was done in the 1990's to the Senate, St. Dominic and St. Augustine squares, and with the Cathedral Square in 2004. In recent years, a comprehensive programme of urban rehabilitation has been focused on the Historical Center of Macao that was adapted for pedestrian use and for beautification. Streets and squares contribute to the classic and vernacular ambience, and they become natural urban connecters to several scattered monuments. These Iberian style urban rehabilitation practices, with a strong local cultural influence attached to Fung Shui principles and the use of the vernacular language, have contributed to preservation of the Macao Cultural Identity.

\section{Conclusions}

The Portuguese follow a few basic principles regarding overseas city settlement. These principles are: A) Strategic geographic position on islands or peninsulas; B) Availability of sheltered bays, and C) Occupation of the mountainous or hilly places. The Iberian urban preferences for settlement were opposed to the Chinese Fung Shui, allowing each community to choose different places that eventually become compatible neighbors with complementary activities. Both the Chinese and the western parts of the city had an organic growth in their urban fabric, which is apparent in the irregular shapes of the streets. Religious compounds clustered western settlers. The Military networks protected the city and contained its development within the walls. This research also concludes that the responsibility for the foundation and preservation of Macao city's predominantly western cultural identity (CI) follows from the Iberian Institutions, particularly the Religious, Military and Civil institutions. They reflect the social stratification of the Portuguese society during the 16 th to 19 th centuries.

City CI is such an important factor that the People's Republic of China proposed to UNESCO that they include Macao in the World Heritage list. For this purpose, several historical buildings and monuments were adapted and maintained in order to preserve the cultural heritage. A comprehensive Programme of urban rehabilitation contemplates the adaptation of the Historical Center of Macao for pedestrian use. Streets and squares become urban connecters that provide a classic ambience and serve as effective links for several scattered monuments. Classical Iberian construction practices and use of a vernacular language contributed to preservation of the Macao Cultural Identity.

\section{References}

[1] Carrol, Warren H (2000) The Cleaving of Christendom. Christendom Press. Front Royal. US 
[2] Cremer, R. D. (1989) Macau, City of Commerce and Culture. UEA Press Hong Kong.

[3] Barros, Joao De (1563) Asia. Terceira Decada. New fac simil edition, printed in 1992 by Imprensa Nacional - Casa da Moeda. Lisboa. Portugal.

[4] Bocarro, Antonio (1642) O livro das plantas de todas as Fortalezas e Povoacoes do Estado da India Oriental. Reprinted in 1992. 260-272. Estampa XLVII. Instituto Nacional Casa da Moeda, Lisboa. Portugal.

[5] Boxer, Charles (1984) Seventeenth Century. Macau. Heinemann Educational books. Ltd. Hong Kong.

[6] Gallende, Pedro (1987) Angels in Stone, Architecture of Augustinian churches in the Phillippines. Formoso
Publishing, Manila.

[7] Javellana, Rene B. (1997).Fortresses of Empire. Bookmark Inc. Manila. Philippines.

[8] Pereira J.F. (1899). Ta-ssi-yang-kuo, 52. DSEJ. Macao.

[9] Pinheiro, Francisco, Yagi, Koji and Korenaga, Miki (2005) JAABE, May 2005. Article on St. Paul College historical role and influence in the development of Macao.

[10] Kaijian, Tang (1998) Notas sobre a evolução urbana e arquitectóica durante a Dinastia Ming. ICM, RC n ${ }^{\circ}$ 34 (II séie), Macau. 